Teologia i Moralność, Volumen 15(2020), numer 1(27)

doi: 10.14746/tim.2020.27.1.04

ORCID: 0000-0001-7965-4266

\author{
MARCIN SZCZODRY \\ Uniwersytet Szczeciński \\ Instytut Nauk Teologicznych
}

\title{
Młodzież w świecie uprzedmiotowionej seksualności. Wyzwanie moralno-duszpasterskie dla Kościoła
}

W ostatnim czasie temat młodych był często obecny w różnych wymiarach życia Kościoła powszechnego. Wystarczy wspomnieć o przygotowaniach do synodu biskupów na temat „Młodzież, wiara i rozeznawanie powołania” (Sinodo dei Vescovi 2017), zwieńczonych dokumentem roboczym, tzw. Instrumentum laboris (Sinodo dei Vescovi 2018a), następnie o pracach samego synodu w październiku 2018 roku oraz o dokumencie końcowym ojców synodalnych (Sinodo dei Vescovi 2018b), jak również o adhortacji apostolskiej papieża Franciszka Christus vivit, podpisanej przez Ojca Świętego w Loreto 25 marca 2019 roku. W tym czasie odbyły się Światowe Dni Młodzieży w Panamie (styczeń 2019). Wydarzenia te pozwoliły spojrzeć na temat młodzieży z wielu perspektyw, dały okazję wypowiedzieć się wielu ekspertom, duszpasterzom oraz samym młodym, pochodzącym z różnych rejonów świata. Poruszono kwestie ważne dla młodzieży, także tematykę związaną z seksualnością człowieka. W adhortacji Christus vivit papież Franciszek zauważył: „Młodzi ludzie przyznają, że ciało i seksualność mają istotne znaczenie dla ich życia oraz rozwoju ich tożsamości. Jednak w świecie, który podkreśla wyłącznie seksualność, trudno jest utrzymać dobrą relację z własnym ciałem i przeżywać spokojnie związki uczuciowe" (ChV, nr 81). Ojcowie synodalni zdają sobie sprawę, że z różnych względów moralność seksualna jest często „powodem niezrozumienia i wyobcowania od Kościoła, ponieważ jest postrzegana jako miejsce sądu i potępienia”, przyznają jednak, że młodzi okazują „wyraźne pragnienie dyskusji na temat kwestii związanych z różnicą pomiędzy tożsamością męską a żeńską, komplementarnością między kobietami a mężczyznami, na temat homoseksualizmu" (Sinodo dei Vescovi 2018b, 39). 
Sfera seksualna jest ważną sferą życia, a czas młodości jest czasem odkrywania jej tajników, uczenia się jej, integrowania w kontekście całej osobowości. Seksualność człowieka, jako dar wpisany w naturę stworzenia, jest czymś dobrym i chcianym przez Stwórcę. Kościół otrzymał misję przekazywania ewangelicznej prawdy o miejscu i celowości ludzkiej seksualności w planie stworzenia i zbawienia. Jest to wizja piękna, aczkolwiek wymagająca. Zadaniem Kościoła jest głosić piękno daru seksualności. Papież Franciszek przypomina, ,że Bóg stworzył nas jako istoty płciowe. On sam «stworzył płciowość, która jest wspaniałym darem dla Jego stworzeń». W ramach powołania do małżeństwa musimy z wdzięcznością uznać, że «płciowość, seks, to dar od Boga, bez jakiegokolwiek tabu. To dar Boży, dar, którym obdarza nas Pan. Ma dwa cele: wzajemną miłość i rodzenie życia. To pasja, namiętna miłość. Prawdziwa miłość jest namiętna. Miłość między mężczyzną a kobietą, gdy jest namiętna, prowadzi cię do dawania życia na zawsze. Zawsze. I do oddania go z ciałem i duszą»" (ChV, nr 261).

Zadaniem więc Kościoła jest ukazywać piękno daru seksualności, przedstawiać światu chrześcijańską wizję seksualności, która człowieka nie ogranicza i nie zubaża, ale wydobywa z niego to, co najwartościowsze. W jakim jednak kontekście kulturowym, społecznym, cywilizacyjnym to przepowiadanie się odbywa? Kim jest jeden z adresatów tego przepowiadania - młodzież? Na jakie problemy napotyka głoszenie ewangelicznej wizji ludzkiej seksualności? Na co powinien zwrócić uwagę Kościół w swojej praktyce duszpastersko-moralnej?

Z tymi pytaniami spróbujemy się skonfrontować, analizując najpierw świat wartości młodego pokolenia oraz świadomość moralną młodzieży. W niniejszym opracowaniu zwrócimy uwagę na polskie środowisko. Następnie przyglądniemy się wybranym zjawiskom we współczesnej kulturze, które z jednej strony utrudniają Kościołowi przebicie się ze swoją wizją ludzkiej seksualności do młodego pokolenia, a z drugiej strony utrudniają młodzieży usłyszenie propozycji, z jaką wychodzi do niej Kościół. Zjawiska te pokazują, w jakim świecie dojrzewają młodzi ludzie, jak bardzo narażeni są na anty-Ewangelię o seksualności, jak często wystawieni są na „ideologiczną kolonizację” (ChV, nr 78) w sferze seksualnej, która wyrządza niepowetowane szkody w ich życiu. Są to zjawiska, w których jasno widać uprzedmiotowienie sfery seksualności. W ostatniej części naszkicowane zostaną wyzwania, przed jakimi stoi Kościół, chcący wejść w świat młodych.

\section{1. Świadomość moralna współczesnej polskiej młodzieży}

Nie jest łatwo zdefiniować kategorię „młodzieży”. W zależności od przyjętych kryteriów mogą pojawić się istotne różnice opisujące i charakteryzujące 
tę grupę społeczną. W socjologii przyjmuje się, że kategoria młodzieży odnosi się do osób, które wyszły z okresu dzieciństwa, osiągnęły dojrzałość płciową, ale jeszcze nie uzyskały dojrzałości społecznej, czyli nie podjęły jeszcze pracy zawodowej albo nie założyły rodziny. Tak szeroka definicja nie jest jednak satysfakcjonująca, zarówno w przestrzeni prawnej, jak i w obszarze badań nad nowymi zjawiskami społecznymi, które domagają się bardziej jednoznacznego kryterium pozwalającego określić, kiedy mamy do czynienia z „młodzieżą". Przyjmuje się więc, że jest to grupa osób w przedziale wiekowym od 11 do 26 lat, z zastrzeżeniem, iż wszelkie sztywne, a nawet administracyjne kryteria wieku nie mogą być stosowane mechanicznie (Grabowska 2014, s. 3).

W ramach przygotowań do synodu biskupów w 2018 roku na temat „Młodzież, wiara i rozeznawanie powołania" Sekretariat Synodu w dokumencie przygotowawczym zaznaczył, że przez pojęcie „młodzieży” należy rozumieć osoby w wieku mniej więcej od 16 do 29 lat, uwzględniając również, że termin ten musi być dostosowany do warunków lokalnych. Należy również pamiętać, że „młodość jest nie tyle określeniem pewnej kategorii osób, ile etapem życia, który każde pokolenie interpretuje na nowo w sposób jedyny i niepowtarzalny" (Sinodo dei Vescovi 2017, I).

Kim zatem jest współczesna młodzież? W jakim świecie wartości żyje? Jakie wartości są dla niej ważne, cenne, jakich dokonuje wyborów? Czy sfera seksualna też wchodzi w obszar etycznej refleksji młodego pokolenia?

Prowadzone przez Centrum Badania Opinii Społecznej od prawie 30 lat badania polskiej młodzieży pozwalają zaobserwować pewne zmiany, jakie zaszły na przestrzeni ponad dwóch dekad w obszarze wartościowania różnych zachowań i postaw dotyczących sfery seksualnej. W systematycznie prowadzonych badaniach (lata 1996, 1998, 2003, 2008, 2010, 2013, 2016), głównie wśród osób mających 18-19, wzięto pod uwagę trzy podstawowe aspekty: (1) akceptację seksu przedmałżeńskiego (małżeństwa jako cezury pozwalającej na rozpoczęcie pożycia seksualnego); (2) akceptację seksu jako wyrazu uczucia poza instytucją małżeństwa; (3) akceptację przelotnych związków seksualnych (seksu w ujęciu hedonistycznym, jako źródła przyjemnych doznań, bez zobowiązań). W 2013 roku badanie poszerzono o jeszcze jeden element - stosunek do prokreacyjnej roli seksu w małżeństwie (Gwiazda 2017a, s. 165). Na podstawie tych badań możemy prześledzić, jak młodzież ocenia konkretne zachowania w sferze seksualnej i jak zmieniło się wartościowanie młodych w odniesieniu do tych tematów na przestrzeni lat.

Młodzi Polacy w większości akceptują seks przedmałżeński, o ile towarzyszy temu uczucie miłości. Ze stwierdzeniem, że pierwsze kontakty seksualne młodzi ludzie powinni mieć dopiero po zawarciu małżeństwa, zgadza się tylko $11 \%$ badanych (w 1996 r. było to $23 \%$ badanych), nie zgadza się aż $70 \%$ młodzieży (w 1996 r. - 54\%). Z tezą, iż to normalne, że kochający się ludzie 
utrzymują ze sobą kontakty seksualne, a ślub nie jest do tego konieczny, zgadza się 77\% respondentów (wzrost o 13\% w porównaniu z 1996 r.), przeciwnych jest $11 \%$ (spadek o 10\%). Mniejszość (ale znacząca) postrzega pozytywnie współżycie seksualne nastawione tylko na doznania zmysłowo-cielesne; $35 \%$ młodzieży zgadza się z twierdzeniem, że seks nie wymaga ani miłości, ani małżeństwa i nawet przelotny związek może dostarczyć przyjemnych, pięknych przeżyć. Nie zgadza się z tym stwierdzeniem 47\% ankietowanych. $\mathrm{Na}$ przestrzeni 20 lat nie zanotowano większych zmian $\mathrm{w}$ odpowiedziach (w 1996 r. kształtowały się one na poziomie 33\% na „tak” i 47\% na „nie”; jedynie w 2003 r. zaobserwowano znaczną zmianę, gdy liczba zwolenników i przeciwników wyrównała się: wtedy $42 \%$ zgadzała się ze zdaniem w ankiecie, 43\% było przeciwnych; natomiast w 2013 r. zaobserwowano największą różnicę między zwolennikami i przeciwnikami podanej tezy, różnica wyniosła 21\%: 31\% na ,tak”, 52\% na „nie”). Dwukrotnie (w 2013 i 2016) spytano, czy młodzi ludzie zgadzają się z twierdzeniem, że głównym celem seksu w małżeństwie jest przede wszystkim prokreacja, czyli posiadanie potomstwa. Twierdząco odpowiedziało 24\% badanych w 2013 roku i 22\% w 2016 roku. Negatywnie, kolejno, 59\% i $61 \%$.

$\mathrm{Z}$ badania wynika, że $54 \%$ badanych ma za sobą inicjację seksualną (61\% chłopców i 45\% dziewcząt). Przeciętny wiek, w którym młodzi ludzie rozpoczynają współżyć seksualnie, to 16 i pół roku w przypadku chłopców i 16 lat i 9 miesięcy wśród dziewcząt. Spośród badanych, którzy mają już za sobą inicjację seksualną i którzy zechcieli odpowiedzieć na kolejne pytanie (autorzy raportu przyznają, że pytanie to okazało się dość drażliwe dla znacznej części młodzieży - blisko 40\% ogółu respondentów odmówiło na nie odpowiedzi), aż 79\% stosuje antykoncepcję - jest to wynik porównywalny z badaniem przeprowadzonym w 1996 roku. Najczęstszym stosowanym środkiem antykoncepcyjnym jest prezerwatywa (76,6\% odpowiedzi) oraz tabletki (pigułki) antykoncepcyjne (22,3\%). Stosunkowo duża liczba młodych osób (52\%) ma wśród znajomych osoby, które zostały rodzicami przed ukończeniem 18. roku życia; $29 \%$ wskazało na kilka takich przypadków.

Warto również przyjrzeć się postawom młodzieży w odniesieniu do problemu aborcji. W badaniach z 2016 roku (Gwiazda 2017b) i 2018 roku (Kawalec 2019) pojawiły się pytania o poziom akceptacji warunków przerwania ciąży. Ocenie poddano siedem sytuacji - cztery, które w obecnym polskim porządku prawnym mogą stanowić przesłankę do legalnej aborcji, oraz trzy, które w świetle obowiązującego dziś prawa są niedopuszczalne. Młodzież w dużym stopniu akceptuje przerwanie ciąży, gdy zagrożone jest życie matki (78\% - 2018 r.; 84\% - 2016 r.; 80\% - 1998 r.), gdy ciąża jest wynikiem gwałtu lub kazirodztwa (według tej samej kolejności lat: 69, 72 i 65\%), gdy zagrożone jest zdrowie matki $(67,72,64 \%)$. Połowa ankietowanych dopuszcza prze- 
prowadzenie aborcji, gdy wiadomo, że dziecko urodzi się upośledzone (36\% jest przeciwnych). Dwadzieścia lat temu $44 \%$ młodych godziło się na aborcję w takim przypadku, $42 \%$ było przeciwnych. Zdecydowana większość negatywnie ocenia sytuację, w której dochodzi do aborcji, gdy kobieta po prostu nie chce mieć dziecka (w 2018 r. - 63\%, w 2016 r. - 73\%, a w 1998 r. - 62\%). Zgadzało się $\mathrm{z}$ tym $\mathrm{w}$ poszczególnych latach 23, 17 i 27\% respondentów. Młodzi nie akceptują aborcji, gdy powodem jest ciężka sytuacja materialna, w jakiej znajduje się kobieta. Przy tym pytaniu zauważa się największe różnice w udzielonych odpowiedziach. W 2018 roku 65\% nie pochwalało aborcji w takich okolicznościach (22\% ją akceptowało); w 2016 roku przeciwników było 74\%, a zwolenników 16\%. W 1998 roku 55\% opowiedziało się przeciw, a $34 \%$ za aborcją ze względu na trudną sytuację materialną matki.

Analizując różne badania socjologiczne nad religijnością i moralnością młodego pokolenia, Jan Dziedzic stwierdza, że „w społeczeństwie polskim wzmacnia się relatywizm moralny oraz częściej niż kiedyś podważa się istnienie niezmiennych i uniwersalnych zasad moralnych. Widoczne jest to przede wszystkim w środowiskach młodzieżowych" (Dziedzic 2017, s. 193).

Przedstawione wyniki badań CBOS-u jednoznacznie pokazują, że młode pokolenie Polaków ma zupełnie inną wizję seksualności niż ta, którą przedstawia Kościół. Zupełnie inaczej ocenia pod kątem moralnym różne zachowania w tej dziedzinie. Jakie są tego przyczyny? Co wpływa na takie postrzeganie sfery seksualnej przez młodzież? Jakie zjawiska wzmacniają przeciwne nauczaniu Kościoła trendy? Na jakie zagrożenia należałoby zwrócić uwagę?

\section{Młodzież w świecie uprzedmiotowionej seksualności}

Świat, w którym żyją młodzi ludzie, stał się w ostatnich latach znacznie bardziej różnorodny i rozległy. Nie ogranicza się on bowiem tylko do obszaru i środowiska, w jakim żyje człowiek (a więc do stosunkowo łatwego w określeniu kontekstu geograficzno-społecznego), ale obejmuje także nieograniczony świat wirtualny. Już papież Benedykt XVI zwrócił uwagę, że „świat cyfrowy nie jest światem paralelnym ani czysto wirtualnym, lecz dla wielu ludzi, zwłaszcza najmłodszych, stanowi część codziennej rzeczywistości” (Benedykt XVI 2013). Autorzy dokumentu końcowego Synodu Biskupów z 2018 roku zauważają, że świat cyfrowy stał się cechą współczesności. To w nim, każdego dnia, duża część ludzkości jest stale zanurzona. „Nie chodzi już tylko o «używanie» narzędzi komunikacji, ale o życie w kulturze głęboko skomputeryzowanej, która ma bardzo mocny wpływ na pojęcie czasu i przestrzeni, na postrzeganie siebie, innych i świata, na sposób komunikowania, uczenia się, zdobywania informacji, nawiązywania relacji z innymi" (Sinodo dei Ve- 
scovi 2018b, 21). Oprócz wielu szans, jakie niosą ze sobą Internet i sieci społecznościowe (jak chociażby możliwość dialogu, spotkań i wymiany między ludźmi, dostęp do wiedzy i informacji), mogą stać się również terenem niebezpiecznym, obszarem samotności, manipulacji, eksploatacji, przemocy, rozpowszechniania pornografii, wykorzystywania osób w celach seksualnych. Mogą również stanowić źródło uzależnienia, izolacji i postępującej utraty kontaktu z rzeczywistościa。 utrudniając rozwój autentycznych relacji międzyludzkich. Świat cyfrowy to również świat gigantycznych interesów ekonomicznych, gdzie dochodzi do próby manipulowania sumieniami i kształtowania określonych poglądów i postaw (Sinodo dei Vescovi 2018b, 22-24). W takim świecie żyją młodzi ludzie - to jest ich świat, w którym na co dzień są obecni; świat, który współtworzą.

W ostatnich badaniach CBOS-u (Feliksiak, Omyła-Rudzka i Bożewicz 2019) na pytanie: „W jaki sposób lubisz najbardziej spędzać czas wolny?”, $25 \%$ odpowiedziało, że na surfowaniu w Internecie, tyle samo osób lubi grać w gry komputerowe, $18 \%$ preferuje oglądanie telewizji, 10\% udzielanie się na portalach społecznościowych. I choć wciąż najpopularniejszymi formami spędzania wolnego czasu są aktywności ze świata „w realu”, czyli spotkania z kolegami, przyjaciółmi, dziewczyną lub chłopakiem, rówieśnikami (86\%) oraz uprawianie sportu (31\%), to oczywiste jest, że świat wirtualny jest również integralną częścią życia młodego pokolenia. To w nim kształtuje się wrażliwość moralna wchodzących $\mathrm{w}$ dorosłość młodych ludzi, to w tym świecie przedstawia się im (często subtelnie, ale w sposób przemyślany) alternatywne wizje ludzkiej seksualności (w badaniu tym respondenci mogli wskazać kilka sposobów spędzania czasu wolnego, dlatego procenty nie sumują się do 100).

Polscy uczniowie spędzają przeciętnie ponad cztery godziny w Internecie na dobę, większość pytanych $(61 \%)$ deklaruje, że w zasadzie cały czas jest online i na bieżąco otrzymuje informacje i reaguje na wiadomości, pozostali (39\%) uruchamiają aplikacje internetowe tylko wówczas, kiedy chcą coś zrobić. Będąc w Internecie, młodzież najwięcej czasu przeznacza na kontakt ze znajomymi, wymianę wiadomości (76\%), słuchanie muzyki (75\%), oglądanie filmów i seriali (56\%), przeglądanie portali społecznościowych, lajkowanie i komentowanie (51\%), oglądanie zdjęć, filmów i materiałów wideo (34\%), oglądanie vlogów, filmów zrobionych przez innych użytkowników, np. na YouTube $(30 \%)$. Najpopularniejszymi portalami społecznościowymi wśród młodych (tych, na których są zarejestrowani i na których mają konto) są Facebook (98\%), YouTube (82\%), Snapchat (76\%) oraz Instagram (72\%) (Feliksiak, Omyła-Rudzka i Bożewicz 2019, s. 203-214).

Wyniki tych badań skłaniają do tego, aby przyjrzeć się, jaki model seksualności promowany jest w miejscach tak chętnie odwiedzanych przez młodych ludzi. Pobieżne przeglądnięcie najpopularniejszych teledysków w sieci lub na 
kanałach muzycznych uprawnia do postawienia tezy, że promowana jest tam czysto zmysłowa strona seksualności. I choć w tekstach piosenek często pojawia się słowo „miłość”, wielokrotnie przeważa jedynie aspekt cielesny (wyraża się to w sylwetce, ubiorze, choreografii, ruchach piosenkarzy i tancerzy).

Po oglądaniu muzyki bardzo dużą popularnością wśród młodzieży cieszy się oglądanie ulubionych seriali w sieci (56\%). Wiele z nich to superprodukcje, w które zaangażowano ogromne pieniądze. Budżet najpopularniejszych obecnie seriali porównywalny jest z budżetami największych kinowych produkcji. Niestety, wśród tych, które przez wiele sezonów cieszyły się największą popularnością (jak choćby „Gra o tron”, „Wikingowie”, „Rodzina Borgiów”, „Tudorowie”), bardzo mocno wyakcentowano sceny przemocy i seksu. Trudno znaleźć odcinek, w którym nie było bardzo wyrazistej sceny erotycznej. Główni bohaterowie oddawali się swojej pożądliwości na różne sposoby, w różnych relacjach i okolicznościach (twórcy seriali zadbali o całą gamę scen erotycznych, są więc sceny aktu heteroseksualnego, homoseksualnego, seks zbiorowy i sceny orgii grupowych, pojawiały się sceny gwałtu, a nawet związków kazirodczych). Taki sposób (bardzo sugestywny w odbiorze u widza, szczególnie młodego) kształtuje spojrzenie na ludzką seksualność i wpływa na odniesienie do sfery intymnej człowieka.

Inną popularną formą spędzania wolnego czasu w Internecie jest wśród młodzieży przeglądanie portali społecznościowych, lajkowanie i komentowanie (51\%), oglądanie zdjęć, filmów i materiałów wideo (34\%). Przestrzeń ta nie jest wolna od zagrożeń, w które wpada spora część młodzieży. W Internecie bardzo łatwo natknąć się na treści pornograficzne i seksualizujące. Wraz z wiekiem wzrasta ryzyko na kontakt z materiałami dotyczącymi seksu w Internecie. Najczęściej na treści związane z seksem młode osoby trafiają przez telewizję, pojawiające się w sieci reklamy, przy użyciu smartfona, w serwisach społecznościowych, w wyskakujących okienkach podczas przeglądania stron internetowych, w reklamach internetowych (Tomczyk 2019). W badaniach przeprowadzonych przez Fundację Dajmy Dzieciom Siłę oraz Instytut Psychologii PAN (Makaruk, Włodarczyk i Michalski 2017) 43\% badanych (w wieku 11-18 lat) miało kontakt z materiałami pornograficznymi i seksualizującymi. Wśród starszych wiekiem wynik jest wyższy: w grupie 15-16 lat wynosi $55 \%$ a w grupie $17-18$ lat - 63\%. Chłopcy oglądają tego typu treści ponad dwa razy częściej niż dziewczęta. Ponad połowa dzieci i młodzieży (58\%) przyznaje, że trafiła na nie przypadkiem. Ankietowani mieli kontakt przede wszystkim ze zdjęciami i filmami pokazującymi nagie osoby $(69 \%)$, ale również ze zdjęciami i filmami pokazującymi stosunek seksualny $(60 \%)$ oraz intymne części ciała (54\%). Aż 22\% osób w wieku 13-18 lat oglądało materiały pornograficzne, w których seks łączył się z przemocą lub robieniem komuś krzywdy. Badania wykazały związek między nadużywaniem Internetu 
a kontaktem z materiałami pornograficznymi i seksualizującymi. Potwierdziły również hipotezę, że osoby mające kontakt z materiałami pornograficznymi i seksualizującymi wykazują ryzykowne zachowania seksualne. Wśród młodych ludzi w wieku 15-18 lat 42\% otrzymało kiedyś od innej osoby jej nagie lub prawie nagie zdjęcie lub film, a 13\% wysłało takie materiały ze swoim udziałem. Należy zauważyć, że osoby, które miały wcześniej kontakt z materiałami pornograficznymi i seksualizującymi, trzykrotnie częściej otrzymywały zdjęcia o charakterze erotycznym i ponad pięć razy częściej je wysyłały.

Zjawisko sekstingu, polegające na przesyłaniu za pośrednictwem sieci lub publikowaniu w Internecie osobistych materiałów o charakterze erotycznym lub pornograficznym, staje się coraz bardziej popularne wśród młodych ludzi, głównie w wyniku rosnącej popularności portali społecznościowych, powszechnego posiadania telefonów komórkowych oraz dostępu do nowych technologii. Różne badania, w zależności od przyjętej metodologii i definicji, wskazują, że problem może dotyczyć od kilku do nawet $40 \%$ dzieci i nastolatków (Wojtasik 2014, s. 79). Wraz z wiekiem wzrasta zjawisko sekstingu (Tomczyk 2019, s. 149). Młodzież często nie zdaje sobie sprawy z zagrożeń wynikających z przekazywania swoich intymnych materiałów innym osobom (szczególnie w sytuacji, gdy prywatne materiały zostaną później upublicznione W sieci). W Internecie można znaleźć portale specjalizujące się w przesyłaniu intymnych zdjęć między użytkownikami. Przekonują, że robienie sobie nagich zdjęć (tzw. nudeski, nudesy, nudle lub nudes) i dzielenie się nimi w Internecie to nic złego. Ludzkie ciało jest piękne, pokazywanie go w takiej formie nie jest niczym złym. Na portalach tych można znaleźć ostrzeżenie, aby zadbać o należytą kontrolę nad tym, kto ma dostęp do naszych zdjęć, aby wyeliminować ryzyko upublicznienia ich postronnym osobom oraz instrukcje, jak zadbać o należyte bezpieczeństwo. Samo jednak zjawisko jest oceniane pozytywnie i przedstawiane jako dobra forma zabawy i pogłębiania znajomości.

Należy zauważyć, że do sekstingu dochodzi zazwyczaj między osobami pozostającymi w związku lub rozpoczynającymi bliższą relację. Wysłanie intymnych zdjęć jest formą „,dowodu miłości”. Bardziej dotknięte sekstingiem są dziewczęta, nakłaniane do tego przez chłopców. Wielu badaczy zajmujących się tym zjawiskiem dostrzega związek sekstingu z innymi szkodliwymi zjawiskami, m.in. cyberprzemocą, czyli przemocą rówieśniczą z użyciem mediów elektronicznych, szantażem (Wojtasik 2014, s. 79-83) i wymuszaniem intymnych zdjęć (Tomczyk 2019, s. 151).

Zjawisko sekstingu dotyka wielu moralnych problemów: traktowania swojego ciała oraz ciała innej osoby, przedmiotowego traktowania seksualności. Mamy tutaj do czynienia ze specyficzną formą podglądactwa. Osoby, które bez żadnych oporów udostępniają swoje intymne zdjęcia i filmy, występują przeciwko cnocie wstydliwości oraz narażają się na pogwałcenie swojej prywatności. 
Istnieje znacznie więcej obszarów, w których zauważa się uprzedmiotowienie cielesności i seksualności. Stanowi to niewątpliwie wyzwanie do dalszych pogłębionych badań, analiz oraz poszukiwania adekwatnej odpowiedzi na rodzące się problemy. Instrumentum laboris synodu na temat młodzieży, wiary i rozeznawania powołania, czyli dokument powstały na podstawie ankiety, którą wypełniły wszystkie Konferencje Episkopatów z całego świata, zwraca uwagę, że współczesny rozwój badań i technologii biomedycznych spowodował zupełnie inne spojrzenie na ludzkie ciało. Jest to efektem coraz śmielszej integracji między ciałem a maszyną. Procesy te sprzyjają technokratycznemu podejściu do cielesności, także z punktu widzenia kontroli dynamizmów biologicznych. Różnego rodzaju eksperymenty i innowacje w dziedzinie chociażby przekazywania ludzkiego życia mają ogromny wpływ na koncepcję ludzkiej cielesności oraz granic moralnych w obrębie działań na ludzkim ciele. Zwrócono również uwagę, że w niektórych kontekstach kulturowych niektórzy młodzi ludzie przejawiają trudności w pogodzeniu się ,z wymiarem swojej stworzoności”, czasami zauważa się wśród nich fascynację „doświadczeniami ekstremalnymi, aż po zagrożenia dla życia, jako okazję do uznania społecznego lub eksperymentowania z silnymi emocjami. Ponadto przedwczesna seksualność, rozwiązłość seksualna, pornografia cyfrowa, pokazywanie swojego ciała online i turystyka seksualna zagrażają oszpeceniem piękna i głębi życia uczuciowego i seksualnego" (Sinodo dei Vescovi 2018a, 52).

\section{Kościół w świecie młodzieży}

W jaki sposób Kościół może wejść w świat młodzieży z przesłaniem o pięknie daru seksualności i o obowiązku wzięcia odpowiedzialności za ten dar? Pewną wskazówkę, jak tego dokonać, podają na zakończenie prac synodalnych uczestniczący w nim biskupi, którzy Dokument końcowy rozpoczynają od przytoczenia historii uczniów z Emaus. Jak wyjaśniają: „W opowieści o uczniach podążających do Emaus (por. Łk 24,13-35) dostrzegliśmy tekst paradygmatyczny dla zrozumienia misji Kościoła w odniesieniu do młodych pokoleń. Ta karta Biblii dobrze wyraża to, czego doświadczyliśmy na Synodzie i to, co chcielibyśmy, aby każdy z naszych Kościołów mógł przeżywać $\mathrm{w}$ relacji z młodymi. Jezus idzie z dwoma uczniami, którzy nie zrozumieli znaczenia Jego historii i oddalali się od Jerozolimy i od wspólnoty. Aby być $\mathrm{w}$ ich towarzystwie, przebywa z nimi drogę. Zadaje im pytania i cierpliwie słucha ich wersji faktów, aby pomóc im rozpoznać to, co przeżywają. Następnie, z czułością i energią, głosi im Słowo, prowadząc ich do interpretowania wydarzeń, które przeżyli w świetle Pisma Świętego. Przyjmuje zaproszenie, by zostać z nimi gdy się ściemnia: wkracza w ich noc. Gdy słuchali, ich ser- 
ce się rozpalało, a ich umysł się rozjaśniał, w łamaniu chleba otworzyły się ich oczy. To oni sami postanawiają bezzwłocznie podjąć drogę w przeciwnym kierunku, by powrócić do wspólnoty, dzieląc się doświadczeniem spotkania ze Zmartwychwstałym" (Sinodo dei Vescovi 2018b, 4).

Rzeczywistość, w jakiej żyją młodzi ludzie, kultura, która kształtuje ich myślenie i sposób wartościowania, nie powinny przerażać Kościoła, ale motywować, aby wszedł on na drogę, którą podąża młody człowiek, wejść w jego historię, słuchać jego pytań i wątpliwości. Nie oznacza to, że przyjmie on od razu i zaakceptuje nauczanie Kościoła w całej jego złożoności. Pasterze Kościoła i wszyscy, którym los młodego pokolenia jest bliski, powinni uzmysłowić sobie, że wejście w świat młodych ludzi jest możliwy i będzie owocny, gdy przyjmie się perspektywę towarzyszenia, a nie narzucania z góry określonych prawd. Jak zauważa Wojciech Giertych, ,samo zadeklarowanie uznania Boga nie wystarcza, aby Jego mocą żyć. Trzeba rozeznać owocność łaski wewnątrz życia, we wszystkich jego wymiarach, a więc nie tylko w jego rozumie i woli, ale także w sferze afektywnej, czyli po części cielesnej, oraz trzeba rozpoznać zachodzące w duszy opory" (Giertych 2015, s. 107). Rzeczywiście, w procesie formowania sumienia należy brać pod uwagę, że czym innym jest świadomość teoretyczna, a czym innym świadomość praktyczno-moralna. Nie wystarczy wiedzieć, co jest dobre, a co złe (nakazane i zakazane), aby być automatycznie związanym w sumieniu w odniesieniu do takiego stanu świadomości. W sumieniu wiąże tylko taki stan wiedzy, który przenikając dogłębnie do wnętrza osoby, pozwala postrzegać dobro w sposób doświadczalny, jako rzeczywistą wartość dla osoby. Zakłada to stopniowe dojrzewanie sumienia, przejście od świadomości konceptualnej, pojęciowej, którą znacznie łatwiej osiągnąć, do świadomości oceniającej i wartościującej, którą można ukształtować jedynie poprzez osobiste zaangażowanie i doświadczenie na drodze formacji sumienia. Świadomość praktyczno-moralna to efekt stopniowego dojrzewania, który charakteryzuje się różnorodnością rytmu i czasu w odniesieniu do poszczególnych osób (Gatti 1990, s. 297). Wszyscy więc, którzy towarzyszą młodym na drodze ich formacji, powinni uzbroić się w cierpliwość i wyrozumiałość. Z kolei młodzież powinna mieć świadomość, że na drodze formacji sumienia, która zakłada stopniowe wchodzenie w rozpoznanie i praktykowanie dobra, cenną i niezbędną pomoc stanowią cnoty męstwa i roztropności (Fumagalli 2017, s. 389-390).

W warstwie treściowej potrzebna jest teologia ciała, która w sposób adekwatny i przystępny opisze łaskę przenikającą do sfery płciowej. Nie wystarczy rozpoznać i opisać grzeszne postępowanie oraz zaproponować odpowiednie normy moralne chroniące przed popełnieniem grzechu. Trzeba pozytywnie pokazać, jak łaska jest w stanie ogarnąć i uzdrowić całego, a więc mającego również wymiar płciowy człowieka (Giertych 2015, s. 107-108). Należy za- 
uważyć, że na gruncie teologicznym w XX wieku zaszły duże zmiany w odniesieniu do tematyki seksualności. Dokonało się to dzięki owocnemu dialogowi teologii z naukami medycznymi, antropologią, psychologią, różnymi kierunkami współczesnej myśli filozoficznej, jak chociażby z fenomenologią, egzystencjalizmem, personalizmem. Przyczyniła się do tego również odnowa biblijna, patrystyczna i liturgiczna. Nie powinno się zapominać o znaczącym wpływie różnych ruchów i wspólnot małżeńskich, które w integralnie ujętej duchowości małżeńskiej ukazały w sposób świeży nowe rozumienie seksualności ludzkiej, ze znaczącymi konsekwencjami na poziomie teoretycznym i pastoralnym (Faggioni 2010, s. 132). Pozostaje jednak jeszcze przenieść owoce teologicznych osiągnięć na język zrozumiały i przystępny młodemu człowiekowi. W tym obszarze jest jeszcze wiele do zrobienia.

Kościół zdaje sobie sprawę, że młody człowiek potrzebuje wychowania także w sferze seksualnej. Jeden z podtytułów posynodalnej adhortacji Amoris laetitia papieża Franciszka zatytułowany jest „«Tak» dla edukacji seksualnej” (AL, nr. 280-286). Edukacja seksualna powinna być jednak osadzona w szerszym kontekście wychowania do miłości. „Dojrzewanie do miłości jest długotrwałym procesem, na który z konieczności winno się nałożyć wychowanie seksualne [...]. Konieczność wychowania seksualnego wynika $\mathrm{z}$ faktu, że człowiek, aby być dojrzałym, musi odnaleźć drogę do pokochania drugiej osoby, czyli osiągnąć zdolność do budowania wspólnoty miłości i małżeństwa. Tę zdolność może nabyć tylko w długotrwałym i trudnym procesie rozwojowym i wychowawczym" (Marcol 1998, s. 137-138). Wychowanie seksualne nie może więc być traktowane jako odrębna dziedzina edukacji, oderwana od innych aspektów wychowania człowieka, lecz powinno być wpisane w całościowy proces edukacyjny, mający na celu integralny rozwój osoby (Olczyk 2018, s. 131).

Nim przystąpi się zatem do układania ambitnych planów pastoralno-katechetyczno-moralnych (które najczęściej koncentrują się na przekazaniu informacji, czyli kształtowaniu świadomości teoretycznej w kwestiach moralnych), należy uzmysłowić sobie, że zadanie jest znacznie poważniejsze, trudniejsze i czasochłonne. Wymaga osobistego zaangażowania i odważnego wkroczenia na długą drogę towarzyszenia młodemu człowiekowi w procesie formowania dojrzałego sumienia. Dobrze, jeśli podczas wspólnej wędrówki nauczy się on zauważać zagrożenia i będzie się umiał przed nimi chronić. Dobrze, jeśli będzie korzystał z możliwości, jakie daje dziś technika, aby pogłębiać swoją wiarę oraz rozumienie nauczania Kościoła w różnych kwestiach, także dotyczących ludzkiej seksualności. Najważniejsze jednak, aby nie pozostawić młodzieży samej, nawet jeśli wydaje się, że nie jest ona zainteresowana propozycją Kościoła albo odnosi się do niej wrogo lub lekceważąco. 


\section{Zakończenie}

Nie ulega wątpliwości, że młodzi żyją dziś i dorastają w świecie, który uprzedmiotawia sferę seksualną. Stanowi to pożądany towar, który dobrze się sprzedaje i z którego szybko można osiągnąć duże zyski. Seksualność wylewa się z różnych stron: z telewizji, Internetu, reklam. Nawet nie chcąc, młody człowiek napotyka na obrazy, których nie chciałby oglądać, a które kształtują jego wyobraźnię, sposób myślenia, wartościowania oraz patrzenia na inne osoby. W tym kontekście warto zwrócić uwagę na zachętę ze strony papieża Franciszka: „Dzisiaj panuje kultura tymczasowości, która jest złudzeniem. Wiara, że nic nie może być ostateczne, to oszustwo i kłamstwo. Często «niektórzy twierdzą, że małżeństwo dziś wyszło z mody [...] W kulturze tymczasowości, względności wielu głosi, że trzeba cieszyć się chwilą, że nie warto angażować się na całe życie, podejmować decyzji ostatecznych [...] Ja natomiast proszę was, abyście byli rewolucyjni, byście szli pod prąd; tak, proszę, abyście w tym względzie buntowali się przeciwko owej kulturze tymczasowości, która w istocie myśli, że nie jesteście zdolni do odpowiedzialności, że nie jesteście w stanie prawdziwie kochać». Ja mam natomiast do was zaufanie i dlatego zachęcam was do obrania małżeństwa. Konieczne jest przygotowanie się do małżeństwa, a to wymaga wychowania siebie samego, rozwijania najlepszych cnót, przede wszystkim miłości, cierpliwości, zdolności do dialogu i służby. Obejmuje ono również wychowywanie swojej seksualności, aby coraz mniej stawała się narzędziem wykorzystywania innych, a coraz bardziej zdolnością do całkowitego dania siebie drugiej osobie, w sposób wyłączny i wielkoduszny" (ChV, nr. 264-265).

Przyglądając się, w jakim świecie i w jakiej kulturze przychodzi wzrastać i dojrzewać młodemu pokoleniu, nie można poprzestać tylko na rozpoznaniu zagrożeń i dawaniu dobrych rad, jak powinno się postępować. Trzeba wejść w świat ludzi młodych, potrzeba nowego języka i sposobu komunikacji, zrozumiałego dla młodzieży. Ze strony Kościoła niezbędne jest odbudowanie zaufania $\mathrm{w}$ obszarach, gdzie jego pasterze i wierni zawiedli (skandale seksualne). Potrzeba także nowych środków dotarcia do młodzieży, uformowanych i dojrzałych duszpasterzy oraz wychowawców znających świat, w którym żyją młodzi ludzie, umiejących przekazać im wymagającą wizję Kościoła dotyczącą seksualności, ale będących równocześnie autentycznymi świadkami, że realizacja tej wizji w życiu przynosi szczęście i radość. W formacji formatorów (duszpasterzy i wychowawców młodzieży) powinno się więc uwzględnić nie tylko przekazanie autentycznej nauki Kościoła oraz ukazanie adekwatnych narzędzi i sposobów, aby ta wizja mogła zainteresować młode pokolenie, lecz równie ważne wydaje się przygotowanie osób pracujących z młodzieżą do długofalowej i cierpliwej pracy, która nie będzie przynosić natychmiastowych owoców i sukcesów. 


\section{YOUTH IN THE WORLD OF SEXUAL OBJECTIFICATION. A MORAL AND PASTORAL CHALLENGE FOR THE CHURCH}

\section{Summary}

Sexuality is an important sphere of life that is particularly explored, learned and integrated in the context of one's personality at the time of youth. Human sexuality, as the gift incorporated into the nature of creation, is good in itself and welcomed by the Maker. It is the task of the Church to present the beauty of this gift and demonstrate to the world the Christian vision of sexuality that does not limit or deprive a man of anything but brings out the best in himself, the most beautiful and valuable aspects. The article aims at asking the crucial questions about cultural, social and civilizationrelated context that gives the framework for the teaching of the Church. The image of contemporary generation of the Polish youth and their values was presented based on most recent sociological research. A selection of contemporary culture phenomena portraying objectified human sexuality was presented. The author outlined challenges that the Church is facing when it tries to enter the world of the youth, pointing out the things to be remembered in the moral and pastoral work.

Keywords: youth; sexuality; sexting; sex education; formation of conscience

Słowa kluczowe: młodzież; seksualność; edukacja seksualna; seksting; formacja sumienia

\section{WYKAZ SKRÓTÓW}

AL - Franciszek Posynodalna adhortacja apostolska «Amoris laetitia».

$\mathrm{ChV}$ - Franciszek Posynodalna adhortacja apostolska «Christus vivit».

\section{BIBLIOGRAFIA}

Benedykt XVI (2013), Orędzie na XLVII Światowy Dzień Środków Spolecznego Przekazu, http:// w2.vatican.va/content/benedict-xvi/pl/messages/communications/documents/hf_ben-xvi_mes_ 20130124_47th-world-communications-day.html [dostęp: 01.06.2019].

Dziedzic J. (2017), Religijność a postawy moralne polskiej młodzieży. Refleksja psychologiczno-pastoralna, w: Młodzież nadzieja Kościoła czy Kościót nadzieją młodzieży?, red. J. Dziedzic, M. Ostrowski, T. Panuś, Kraków, s. 187-203.

Faggioni M.P. (2010), Sessualità, matrimonio, famiglia, Bologna.

Feliksiak M., Omyła-Rudzka M., Bożewicz M. (2019), Zainteresowania i aktywności, w: Młodzież 2018, red. M. Grabowska, M. Gwiazda, Warszawa, s. 176-226.

Franciszek (2016), Posynodalna adhortacja apostolska «Amoris laetitia».

Franciszek (2019), Posynodalna adhortacja apostolska «Christus vivit». 
Fumagalli A. (2017), L'amore sessuale. Fondamenti e criteri teologico-morali, Brescia

Gatti G. (1990), Educazione morale, w: Nuovo Dizionario di Teologia Morale, red. F. Compagnoni, G. Piana, S. Privitera, Cinisello Balsamo.

Giertych W. (2015), Fides et passio, Pelplin.

Grabowska M. (2014), Dzisiejsza młodzież-pokolenie XYZ...?, w: Młodzież 2013, red. M. Grabowska, J. Kalka, Warszawa, s. 3-8.

Gwiazda M. 2017a. Młodzież i seks, w: Młodzież 2016, red. M. Grabowska, M. Gwiazda, Warszawa, s. $165-170$.

Gwiazda M. (2017b), Stosunek do aborcji, w: Młodzież 2016, red. M. Grabowska, M. Gwiazda, Warszawa, s. 171-177.

Kawalec I. (2019), Stosunek do aborcji, w: Młodzież 2018, red. M. Grabowska, M. Gwiazda, Warszawa, s. 170-175.

Makaruk K., Włodarczyk J., Michalski P. (2017), Kontakt dzieci i młodzieży z materiałami pornograficznymi i seksualizującymi. Analiza zjawiska na podstawie wyników ogólnopolskiego badania uczniów, „Dziecko Krzywdzone. Teorie, Badania, Praktyka” 16(3), s. 37-63.

Marcol A. (1998), Etyka życia seksualnego. Opole.

Olczyk M. (2018), Edukacja seksualna jako wychowanie do miłości. Niezmienne pryncypia i nowe wyzwania w świetle Amoris laetitia 259-290, „Teologia i Moralność” 23, s. 125-139. DOI: https://doi.org/10.14746/tim.2018.23.1.7

Sinodo dei Vescovi (2018b), Documento finale e Votazioni del Documento finale del Sinodo dei Vescovi al Santo Padre Francesco, http://press.vatican.va/content/salastampa/it/bollettino/pubblico/2018/10/27/0789/01722.html [dostęp: 01.06.2019].

Sinodo dei Vescovi (2017), Documento preparatorio "I giovani, la fede e il discernimento vocazionale», http://www.vatican.va/roman_curia/synod/documents/rc_synod_doc_20170113_documento-preparatorio-xv it.html [dostęp: 01.06.2019].

Sinodo dei Vescovi (2018a) Instrumentum laboris "I giovani, la fede e il discernimento vocazionale», http://www.vatican.va/roman_curia/synod/documents/rc_synod_doc_20180508_instrumentum-xvassemblea-giovani_it.html [dostęp: 01.06.2019].

Tomczyk Ł. (2019), Materiały dotyczące seksu i zjawisko sekstingu, w: Polskie badanie EU Kids Online 2018. Najważniejsze wyniki i wnioski, red. J. Pyżalski i in., Poznań, s. 137-154.

Wojtasik Ł. (2014), Seksting wśród dzieci i młodzieży, „Dziecko Krzywdzone. Teorie, badania, praktyka" 13(2), s. 79-98.

MArCIN Szczodry - ks. dr, adiunkt w Instytucie Nauk Teologicznych Uniwersytetu Szczecińskiego. Prowadzi badania w zakresie teologii moralnej i bioetyki. e-mail: marcin.szczodry@usz.edu.pl 